EDITED BY ROBERT REZETKO, TIMOTHY H. LIM AND

W. BRIAN AUCKER

Reflection and

Refraction

Studies in Biblical Historiography in Honour of A. Graeme Auld 


\section{ISRAEL'S SOJOURN IN THE WILDERNESS AND THE CONSTRUCTION OF THE BOOK OF NUMBERS ${ }^{\prime}$}

Thomas Ghristian Römer

\section{Introduction}

The lack of any consensus is probably the first thought that comes to mind when one tries to describe the current state of historical and critical Pentateuchal research. A growing number of authors, especially in Europe, have given up the traditional documentary hypothesis, which by the way is still popular in textbooks and publications for larger audiences. The idea that a tenth century Yahwist created the narrative structure of the Pentateuch (or Hexateuch) starting with the creation of the world and ending with Israel's entrance into the Promised Land, or that he even inherited this structure in an oral form, has become a very difficult and dubious assumption. Archaeological, socio-historical and literary reasons no longer allow one to locate the edition of the first 'Pentateuchal narrative' at the beginning of Israelite monarchy.

It is not my concern in this context to provide an overview of every issue in the current debate. We will restrict ourselves to the question of the origin of the Pentateuchal or Hexateuchal narrative. This question may also be formulated in the following way: When were all the so-called major themes of the Pentateuch or Hexateuch (primeval history, the Patriarchal narratives, the epic of the exodus, the lawgiving on mount Sinai, the sojourn of Israel in the wilderness, the conquest of the land) combined for the first time? This debate will open new perspectives on the formation of the book of Numbers.

${ }^{1}$ This paper was given at the SOTS meeting, January 2005, in Birmingham under the presidency of Professor A. G. Auld. It is my pleasure to offer these houghts to an esteemed colleague and a very good friend. 


\section{The Question of a Pre-Priestly Pentateuch}

Despite the apparent lack of consensus, there is a general agreement that the second half of the Persian period saw the birth of the Torah and of Judaism as a Torah-related religion. But where did the conception of the narrative structure of this Torah originate? A number of scholars still postulate a Yahwistic document as the nucleus of the Pentateuch. Given the fact that von Rad's idea of a Yahwist writing in the time of a chimeric 'Solomonic enlightenment' is no longer tenable, some authors return to Wellhausen's view of J (or $\mathrm{JE}$ ) as a work from the monarchical period (thus in particular Nicholson, Seebass). ${ }^{2}$

Martin Rose follows the intuitions of H. H. Schmid's book on the 'so-called Yahwist', who had emphasised the deuteronomistic influence on the vocabulary and ideology of the texts, which Noth had attributed to J. ${ }^{3}$ Rose transforms J into a Deuteronomist of the second or third generation, and considers his work in Genesis to Numbers as a prologue and, simultaneously, a 'theological amendment' to the Deuteronomistic History. ${ }^{4}$ This approach is quite close to the distinction, in the Pentateuch, between a D-composition prefacing the Deuteronomistic History and a P-composition, as postulated by E. Blum and others. ${ }^{5}$ Quite similarly, John Van Seters considers the Yahwist as a later expansion of the Deuteronomist's work. ${ }^{6}$ But in

${ }^{2}$ E. W. Nicholson, The Pentateuch in the Twentieth Century: The Legacy of Julius Wellhausen (Oxford: Clarendon Press, 1998); H. Seebass, 'Pentateuch', TRE 26:185-209. ${ }^{3}$ H. H. Schmid, Der sogenannte Fahwirst: Beobachtungen und Fragen zur Pentateuchforschung (Zürich: Theologischer Verlag, 1976).

M. Rose, Deuteronomist und Fahwist: Untersuchungen zu den Berührungspunkten beider Literaturwerke (ATANT, 67; Zürich: Theologischer Verlag, 1981); for the same approach see F. H. Cryer, 'On the Relationship between the Yahwistic and the Deuteronomistic Histories', BN 29 (1985), pp. 58-74

E. Blum, Studien zur Komposition des Pentateuch (BZAW, 189: Berlin: W de Gruyter 1990); see also W. Johnstone, "The Deuteronomistic Cycles of "Signs" and "Wonders" in Exodus 1-13', in A. G. Auld (ed), Understanding Poets and Prophets: Essars in Honour of George Wishart Anderson (JSOTSup, 152. Sheffield. Sheffield Acade Essays in Honour of George Wishart Anderson (JSOTSup, 152; Sheffield: Sheffield Academic Press, 1993) pp. 166-85; F. García López, 'Deut 34, Dtr History and the Pentateuch', in F. García Martínez et al. (eds.), Studies in Deuteronomy: In Honour of C. 7. Labuschagne the Occasion of his 65th Birthday (VTSup, 53; Leiden: E. J. Brill, 1994), pp. 47-61. Theologischer Verlag 1992); see also: The Tahwirst as Historian in Genesis (Zürich: Theologischer Verlag, 1992), see also idem, The Life of Moses: The Yahwirst as Historian in Exs, 1994). For (Kampen. Kok Pharos, Louisville, KY. Westminster/John Knox Press, 1994). For the primeval history, Van Seters suggests that $J$ is directly dependent on the Babylonian version of the Flood, which is conserved in the Epic of contrast to the Yahwist of Rose and the D composition of Blum, Van Seters' Yahwist is above all an antiquarian historian who freely composes his work. $J$ is a contemporary of Second Isaiah and close to his universal perspective.

Christoph Levin ${ }^{7}$ also locates $\mathrm{J}$ in the exilic period, later than the book of Deuteronomy, but nevertheless earlier than the Deuteronomistic History. J represents the perspective of a more popular type of religiosity, as well as the concerns of the Diaspora; as such, he defends the diversity of cultic places where Yahweh may be worshipped contra the authors of Deuteronomy. According to Levin, $\mathrm{J}$ is foremost a collector and a redactor; he is the first to organise his older sources into a narrative, which covers (more or less) the extent of the Pentateuch. ${ }^{8}$ Levin actually combines in his description of the work of the Yahwist a fragment theory with a supplementary theory, since more than half of the non-priestly texts of the Pentateuch are supplements added to the Yahwistic work by numerous redactors.

The problem of all these Yahwists (or 'Deuteronomists') is that they tend to become very elusive after the exodus story. The recent reconstruction of the Yahwistic history by Levin reveals that a concentration of $82 \%$ of the $\mathrm{J}$ document is found in Genesis. The J-text after the arrival in the wilderness is limited (after Exodus $\left.16-18^{*}\right)$ to Exod *19.2-3; 24.18; 34.5, 9a, 28a; Num 10.12, 29-31, $33 ; 11.2,4,11,23,31-32 ; 20.1 ; 22.1-8,12,21-22,36,41 ; 23.2$; 24.1, 3-6, 9-11, 25; 25.1; Deut 34.5-6.*

The concentration of the so-called Yahwist to the book of Genesis is nothing new. Since the nineteenth century, the entire documentary hypothesis, including the notion of a Yahwistic document, was indeed essentially elaborated through analyses of the book of Genesis. Significantly, and for all the differences in the various conceptions of $\mathrm{J}$ in a little more than two centuries, it appears that up to now the book of Genesis remains the basis for the study of J. One may

${ }^{7}$ G. ${ }^{8}$ In a recent article Levin still argues, as in his book, that the end of $\mathrm{J}$ may be lost, cf. C. Levin, 'Das israelitische Nationalepos: Der Jahwist', in M. Hose (ed.), Große Texte alter Kulturen: Literarische Reise von Gizeh nach Rom (Darmstadt: Wissenschaftliche Buchgesellschaft, 2004), pp. 63-86 (74). However, in a recent reconstruction of J which Prof. Levin kindly sent to me, he identifies the end of J in Num 25.1 and Deut $34.5-6^{*}$. 
therefore wonder whether the so-called Yahwist should not be limited to Genesis, as was already suggested by Winnett ${ }^{9}$ and, more recently, by Kratz. ${ }^{10}$

Such an idea (if one wishes to keep the siglum ' $\mathrm{J}$ ', which is not really necessary) would gain support from another new trend in the current research on the Torah: the emphasis on the ideological and literary gap between the Patriarchs and Exodus. In a recent study, Konrad Schmid, ${ }^{11}$ building on earlier works of Winnett, de Pury and others, ${ }^{12}$ has argued that the literary link between Genesis and Exodus was only created by the Priestly document. According to Schmid the earliest literary links between the Patriarchal narratives and the Exodus story belong to $\mathrm{P}$, especially Genesis 17 and Exodus 6. The debate is, of course, open, ${ }^{13}$ but there is nevertheless a trend to

F. V. Winnett, The Mosaic Tradition (Near and Middle East Series, 1; Toronto: University of Toronto Press, 1949).

${ }_{10}$ R. G. Kratz, Die Komposition der erzählenden Bücher des Alten Testaments: Grundwiissen der Bibelkritik (Uni-Taschenbücher für Wissenschaft, 2157; Göttingen: Vandenhoeck \& Ruprecht, 2000), pp. 249-330. Kratz limits J to Genesis 1-36*; he labels ' $E$ ' the \& Rupal Exodus story running from Exodus $1 *$ to Genesis 1-36*

$11 \mathrm{~K}$ Sxodus story running from Exodus 1 to Josha $12^{*}$. V 1999). (2)er Verlag, 1999).

${ }_{12}$ F. V. Winnett, 'Re-examining the Foundations', $7 B L 84$ (1965), pp. 1-19; A. de Pury, 'Las dos leyendas sobre el origen de Israel (Jacob y Moisés) y la elaA. Pón , 'Las dos ley boracion del Pentateuco, EstBib 52 (1994), pp. 95-131; idem, "Abraham: The Priestly Writer's "Lcumenical" Ancestor, , in S. L. McKenzie, T. Romer and H. H. Schmid (eds.), Rethinking the Foundations. Historiography in the Ancient World and in the Bible: Essays in Honour of John Van Seters (BZAW, 294; Berlin. W. de Gruyter, 2000), pp. 163-81; T. Römer, Israels Vater: Untersuchungen zur Vaterthematik im Deuteronomium und in de deuteronomistischen Tradition (OBO, 99; Freiburg: Universitätsverlag; Göttingen: Vandenhoeck \& Ruprecht, 1990); idem, 'Deuteronomy in Search of Origins', in G. N. Knoppers and J. G. McConville (eds.), Reconsidering Israel and Fudah: Recent Studies on the Deuteronomistic History (Sources for Biblical and Theological Study, 8; Winona Lake, IN: Eisenbrauns, 2000), pp. 112-38. That the Patriarchal narratives and the Exodus story represent two competing origin traditions was already argued by W. Staerk, Studien zur Religions- und Sprachgeschichte des alten Testaments (2 vols; Berlin: Georg Reimer, 1899) and K. Galling, Die Erwählungstraditionen Israels (BZAW, 48; Giessen: Alfred Töpelmann, 1928). But for these authors both traditions were already linked in the time of the Jehovist or even earlier.

For P as creator of the link between Genesis and Exodus see also J. C. Gertz Tradition und Redaktion in der Exoduserzählung: Untersuchungen zur Endredaktion des Pentateuch (FRLANT, 186; Göttingen: Vandenhoeck \& Ruprecht, 1999); E. Otto, Das Deuteronomium im Pentateuch und Hexateuch: Studien zur Literaturgeschichte von Pentateuch und Hexateuch im Lichte des Deuteronomiumsrahmens (FAT, 30; Tübingen: Mohr Siebeck, 2000). For a critical evaluation see G. Davies, 'The Final Redaction of the Pentateuch', SOTS Summer Meeting 2001 (http://www.trinity-bris.ac.uk/sots/conferences2001.html). underline the literary and theological differences between Genesis and the following books of the Torah. This is, for instance, the case of E. Blum, who has modified his former hypothesis about the Pentateuch as a compromise between a 'D composition' and a ' $P$ composition'. He now argues that the $\mathrm{D}$ composition started with the story of Moses and did not include the Genesis traditions. ${ }^{14}$ And even among scholars who do not agree with the idea of $\mathrm{P}$ as the first document to link Patriarchs and Exodus there is a growing tendency to consider this link as not original and 'late'. ${ }^{15}$

The present debate on the Yahwist and the link between Patriarchs and Exodus clearly reveals that it is very difficult to maintain the idea of a pre-priestly document which would have constituted a kind of Proto-Pentateuch, comprising all of its major themes. Should one therefore return to Martin Noth's claim that $\mathrm{P}^{\mathrm{g}}$ (the first edition of the Priestly document) constitutes the skeleton of the Pentateuch? ${ }^{16}$ But this statement also raises a number of problems.

\section{The Problem of a Priestly Pentateuch}

For Noth and many other scholars there was no doubt that $\mathrm{P}$ ended in Deut 34.1a $\ldots$. . 7-9. ${ }^{17}$ Nevertheless, this opinion does not match

${ }^{14}$ E. Blum, 'Die literarische Verbindung von Erzvätern und Exodus: Ein Gespräch mit neueren Forschungshypothesen', in J. C. Gertz, K. Schmid and M. Witte (eds.), Abschied vom Fahwisten: Die Komposition des Hexateuch in der jüngsten Diskussion (BZAW, 315; Berlin: W. de Gruyter, 2002), pp. 119-56.

See for instance D. M. Carr, 'Genesis in Relation to the Moses Story: Diachronic and Synchronic Perspectives', in A. Wénin (ed.), Studies in the Book of Genesis: Literature, Redaction and History (BETL, 155; Leuven: Peeters and Leuven University Press, 2001), pp. 273-95; W. Johnstone, 'The Use of Reminiscences in Deuteronomy in Recovering the Two Main Literary Phases in the Production of the Pentateuch', in Gertz, Abschied vom Fahwisten, pp. 247-73; R. Albertz, Israel in Exile: The Histor and Literature of the Sixth Century B.C.E. (trans. D. E. Green; Studies in Biblical Literature, 3; Atlanta: Society of Biblical Literature, 2003); E. Aurelius, Zukunft jenseits des Gerichts: Eine redaktionsgeschichtliche Studie zum Enneateuch (BZAW, 319; Berlin: W. de Gruyter, 2003)

${ }^{16}$ M. Noth, A History of Pentateuchal Traditions (trans. B. W. Anderson; Englewood Cliffs, NJ: Prentice-Hall, 1972; repr.: Chico, CA: Scholars Press, 1981). For a recent defence of Noth's position with some modifications see C. Frevel, Mit Blick auf das Land die Schöpfung erinnern: zum Ende der Priestergrundschrift (Herders Biblische Studien, 23; Freiburg: Herder, 1999).

17 Noth, Pentateuchal Traditions, pp. 16-19. According to Noth, the redactor omitted P's report of Moses' death because he wanted to keep the older account in vv. 
the function and the style of these verses. The emphasis on Joshua as Moses' successor does not sound like a conclusion, but an indication that the story will move on to the conquest. As to the vocabulary and expressions of 34.7-9, Lothar Perlitt has convincingly shown that these verses cannot be attributed to the original priestly document; they reveal a mixture of priestly and deuteronomistic expressions and conceptions, which can be found in the latest layers of the Pentateuch. ${ }^{18}$

If $\mathrm{P}^{\mathrm{g}}$ cannot be detected in Deuteronomy 34, where did it end? Some scholars try to rehabilitate the idea that the priestly document did cover a Hexateuchal narrative and postulate its ending either in Josh 18.1 ('the whole congregation of the Israelites assembled at Shiloh, and set up the tent of meeting there. The land lay subdued before them') or in 19.51 ('. . . So they finished dividing the land'). ${ }^{19}$ It is often argued that such a conclusion would buttress the fulfilment of P's presentation of God's initial order to mankind in Gen 1.28 (to subdue the earth). But Gen 1.28 is directed to humanity in its entirety and has nothing to do with Israel's occupation of the land ${ }^{20}$ and P's presentation of God's revelation in three steps (elohim for all mankind, el shadday for Abraham's descendants, and yhwh for Israel whose mediator is Moses) clearly shows that $\mathrm{P}^{\mathrm{g}}$ 's main interest resides

${ }^{18}$ L. Perlitt, 'Priesterschrift im Deuteronomium?', ZAW 100 (Supplement 1988), pp. 65-88 = Deuteronomium-Studien (FAT, 8; Tübingen: Mohr Siebeck, 1994), pp 123-43; see also P. Stoellger, 'Deuteronomium 34 ohne Priesterschrift', ZAW 105 (1993), pp. 26-51.

${ }^{19}$ See Seebass, 'Pentateuch', p. 192; E. A. Knauf, 'Die Priesterschrift und die Geschichten der Deuteronomisten', in T. Römer (ed.), The Future of the Deuteronomistic History (BETL, 147; Leuven: Peeters and Leuven University Press, 2000), pp. 101-18 N. Lohfink, 'The Priestly Narrative and History', in N. Lohfink, Theology of the Pentateuch: Themes of the Priestly Narrative and Deuteronomy (trans. L. M. Maloney; Edinburgh: T\&T Clark; Minneapolis: Fortress Press, 1994), pp. 136-72; J. Blenkinsopp The Pentateuch: An Introduction to the First Five Books of the Bible (ABRL; Garden City, NY: Doubleday, 1992), p. 237

${ }^{20}$ According to $\mathrm{P}^{\mathrm{g}}$, the initial order of Gen 1.28 is perverted in Gen 6.11-12 and restored in a modified way after the Flood. One should also underline that the root $k b s$ (niphal) also occurs in Num 32.22, 29 (in the same way as in Josh 18.1) but the verses in Numbers are commonly considered post-P. So it would be better to ascribe Josh 18.1 to the same late redactional level (see for instance R. Achenbach, Die Vollendung der Tora: Studien zur Redaktionsgeschichte des Numeribuches im Kontext von Hexateuch und Pentateuch [Beihefte der Zeitschrift für altorientalische und biblische Rechtsgeschichte, 3; Wiesbaden: Otto Harrassowitz, 2003], p. 386). in Grod's revelation to his people and not in Israel's occupation of the land. ${ }^{21}$

If neither Deuteronomy 34 nor the end of Joshua offers a comprehensive conclusion for $\mathrm{P}^{\mathrm{g}}$, the end of the original priestly writing must be looked for somewhere earlier. The book of Numbers can easily be excluded:22 the so-called priestly texts of this book differ in style and ideology from those commonly ascribed to the original priestly document: the rebellion stories conflict with the priestly anthropology according to which human beings cannot act against the divine will; the presentation of Israel as an ecclesia militans does not fit well with the so-called pacifism of $\mathrm{P} .^{23}$

Given the fact that there are no clear traces of $\mathrm{P}^{\mathrm{g}}$ in the book of Numbers its conclusion should be located in God's revelation to Israel on Mount Sinai. Thomas Pola put this idea forward; ${ }^{24}$ he reconstructed the final scene of the priestly document in Exod 40.16-17a, 33b. Even if one may question Pola's literary-critical operations on the Sinai-pericope, ${ }^{25}$ his idea that Yhwh's dwelling in his mobile sanctuary is a fitting conclusion is now accepted by a growing number of scholars, even if there are some discrepancies as to the exact ending of $\mathrm{P}^{\mathrm{g}} .{ }^{26}$ Indeed, Exodus 40 constitutes a convincing

${ }^{21}$ R. W. Klein, 'The Message of P', in J. Jeremias and L. Perlitt (eds.), Die Botschaft und die Boten: Festschrift für Hans Walter Wolff zum 70. Geburtstag (NeukirchenVluyn: Neukirchener Verlag, 1981), pp. 57-66; M. Köckert, 'Das Land in der priesterlichen Komposition des Pentateuch', in D. Vieweger and E.-J. Waschke (eds.) Von Gott reden: Beiträge zur Theologie und Exegese des Alten Testaments: Festschrift fuir Siegfried Wagner zum 65. Geburtstag (Neukirchen-Vluyn: Neukirchener Verlag, 1995), pp. 147-62; M. Bauks, "Une histoire sans fin": L'impasse herméneutique de la notion de pays dans œuvre sacerdotale (Pg)', ETR 78 (2003), pp. 255-68.

Some scholars nevertheless try to discover P's end in Numbers. Ska (J-L Ska Introduction à la lecture du Pentateuque. Clés pour l'interprétation des cinq premiers livres de la Bible [Le livre et le rouleau, 5; Bruxelles: Lessius, 2000], pp. 210-15) and García López (F. García López, El Pentateuco. Introducción a la lectura de los cinco primeros libros de la Biblia [Introducción al estudio de la Biblia, 3a; Estella: Verbo Divino, 2003] pp. 332-33) postulate Numbers 27; but may the announcement of Moses, 2003], and the installation of Joshua as his successor be considered as a fittinges end ${ }^{23}$ See on this point E. Aurelius, Der Fürbitter Israels: Fine Studie zum Mosebild i Alten Testament (ConBOT, 27; Stockholm: Almqvist \& Wiksell, 1988) ${ }_{24}$ T. Pola Die urspriungliche Priesterschinft: Beobarnquist \& Wiksell, 1988), pp. 187-202. von $P^{g}$ (WMANT, 70; Neukirchen-Vluyn: Neukirchener Verlag, 1995).

${ }^{25}$ Pola only considers about two (!) percent of the present text of Exodus 25-40 as belonging to $\mathrm{P}^{\mathrm{g}}$, which seems quite implausible.

${ }^{26}$ According to E. Otto, Pg ended at Exod 29.42b-46 ("Forschungen zur Priesterschrift', TRu 62 [1997], pp. 1-50); for Exod 40.34b as an ending see 
ending of the priestly story that started in Genesis $1:^{27}$ that the creation and construction of a sanctuary belong together is attested in Near-eastern parallels, ${ }^{28}$ and the installation of Israel's cult is certainly a main concern of $\mathrm{P}$. One may ask if, in this case, the consecration of Israel's first priests in Lev 9.23-24 would not even be a better ending, ${ }^{29}$ but for our present purposes this debate may be left open.

The consequence of the current trend of Pentateuchal research is therefore that neither the so-called Yahwist nor the original Priestly document contains a narrative strand that comprises the whole Pentateuch (or Hexateuch). On the one hand there is a priestly 'Tritoteuch', which covers the narrative from creation of the world to the installation of Israel's worship; on the other hand we have the book of Deuteronomy, which is closely related in style and ideology to the Former Prophets, either as a prologue of a 'Deuteronomistic History' or for having underwent analogue deuteronomistic redactions as the books of Joshua to Kings. ${ }^{30}$

M. Bauks, 'La signification de l'espace et du temps dans "l'historiographie sacerdotale"', in Römer, The Future of the Deuteronomistic History, pp. 29-45; C. Levin, Das Alte Testament (C. H. Beck Wissen in der Beck'shen Reihe, 2160; Munich: C. H. Beck, 2001), p. 80; and Kratz, Komposition, p. 108.

${ }^{27}$ See Blenkinsopp, Pentateuch, p. 218, for parallels between Gen 1.1//Exod 39.43; Gen 2.1//Exod 39.43; Gen 2.2//Exod 40.33; Gen 2.3//Exod 39.43.

${ }^{28} \mathrm{M}$. Weinfeld, 'Sabbath, Temple and the Enthronement of the Lord - The Problem of the Sitz im Leben of Genesis 1:1-2:3', in A. Caquot and M. Delcor (eds.), Mélanges bibliques et orientaux en l'honneur de M. Henri Cazelles (AOAT, 212; Kevelaer: Butzon \& Bercker; Neukirchen-Vluyn: Neukirchener Verlag, 1981), pp. 501-12.

${ }_{29}$ This solution is advocated by E. Zenger, 'Priesterschrift', TRE 27:435-46. The problem with this solution is that Lev 9.23 presupposes Exod 40.35a, which is often considered an interpolation. Maybe one could follow Kratz, Komposition, p. 116, who argues that most texts in Leviticus 1-16* were added to P before P was combined argues that most texts in Leviticus $1-16^{*}$ were added to $\mathrm{P}$ before $\mathrm{P}$ was combined C. Nihan 'From Priestly Torah to Pentateuch' (ThD thesis, University of Lausanne, to be published in FAT

${ }_{30}$ I cannot take up, in this context, the debate of the existence of the so-called I cannot take up, in this context, the debate of the existence of the so-called Deuteronomistic History. Even if it has become fashionable to deny the existence of such a construct, there is in my view no better explanation for the fact that the books from Deuteronony to redactions, see T. Rom nomistic History', in M. A. Sweeney and $\mathrm{E}$. Ben Zvi (eds.), The Changing Face of Form Criticism for the Twenty-First Century (Grand Rapids: Eerdmans, 2003), pp. 240-52. For the opposite view, see especially A. G. Auld, The Deuteronomists and the Former Prophets, or What Makes the Former Prophets Deuteronomistic?', in L. S. Schearing S. L.
This brings us to the book of Numbers, which is the least easily characterised of the five books of the Torah. There is no trouble in indicating the structure and the arrangement of the books of Genesis, Exodus, Leviticus and Deuteronomy. But if one tries to do the same with Numbers the task is more difficult; Numbers is indeed the only book of the Pentateuch where commentators need several pages to justify their idea of the structure of the book and to refute others. Numbers apparently has no obvious arrangement; this may be explained by the fact that Numbers was the last book of the Torah, which came into existence at a time when Genesis, Exodus, Leviticus on the one hand and Deuteronomy on the other hand were already shaped. This means that the book of Numbers was created to integrate the latest texts of the Torah. The redactional model explaining the formation of the book of Numbers may therefore be different from those applied to the other books of the Pentateuch. Before sketching some preliminary thoughts about the formation of Numbers in regard to the wilderness traditions, some further indications on the proto-midrashic ${ }^{31}$ character of the book seem to be appropriate.

\section{The Book of Numbers as a Forerunner of Midrashic Literature}

Martin Noth made two important statements on the book of Numbers. The first is the oft quoted observation in the introduction of his commentary on Numbers: Were we to 'take the book of Numbers on its own, then we would think not so much of "continuous sources" as of an unsystematic collection of innumerable pieces of tradition of very varied content'. ${ }^{32}$ The second statement is the assertion that almost all texts in Numbers 27-36 are post-priestly texts, added

${ }^{31}$ I am aware of the often unreflective use of 'midrashic' by biblical scholars. It is certainly right that this term should be limited to rabbinical literature and not be used as a fancy term for 'interpretation'. Nevertheless, I am quite convinced that the construction of Numbers foreshadows in a certain way the latter idea of 'oral Torah' See now T. Relation to the Hebrew Scriptures', in J Neusner and A J. Avery-Peck (eds. Encyclopedia of Midrash. Biblical Interpretation in Formative and A. J. Avery-Peck (eds.), pp. 595-612. Therefore I feel authorised to speak about 'proto-midrashic' writing in relation to the book of Number.

${ }_{32}$ M. Noth, Numbers: A Commentary (trans. J. D. Martin; OTL; Philadelphia: Westminster Press, 1968), p. 4. 
successively one after the other. ${ }^{33}$ This idea of a rolling corpus, which is characterised by the observation that pre-existing texts or traditions trigger exegesis or commentary, advocated by William McKane to explain the formation of the book of Jeremiah, ${ }^{34}$ may also apply to other parts of the book of Numbers.

First of all it is interesting to look at the opening and the conclusion of Numbers and to compare these with the opening and concluding verses of Leviticus:

Lev 1.1: 'He called Moses. Thwh spoke to him from the tent of meeting, saying'.

Lev 27.34: 'These are the commandments that Thwh commanded to Moses for the Israelites on Mount Sinai'.

Num 1.1: 'Thwo spoke to Moses in the desert of Sinai, in the tent of meeting ... saying'.

Num 36.12: 'These are the commandments and the ordinances that Thwh commanded through Moses to the Israelites in the plains of Moab by the Jordan at Jericho'.

Numbers 1.1 clearly takes up the beginning and ending of Leviticus, nevertheless introducing an important difference: ${ }^{35}$ the commandments in Numbers are revealed no longer on Mount Sinai, but in the desert of Sinai. This is a hint that the editors of Numbers understood the laws in Numbers as not having directly emerged from God's revelation on Mount Sinai, but as supplements given later, still in relation with 'Sinai' but located in the 'desert' and not on Yhwh's mountain. Is there a better way to indicate that the laws collected in Numbers are supplements to the 'original' priestly and deuteronomistic revelation of the Law?

A short overview of Numbers 1-10 confirms this observation. Most of the prescriptions in these chapters would have better fit into the books of Exodus, Leviticus instead of Deuteronomy; apparently it was impossible to interpolate them in these books, which were already more or less closed to important additions. The ordeal in Numbers

${ }^{33}$ Noth, Numbers, p. 8; see already M. Noth, Überlieferungsgeschichtliche Studien: Die sammelnden und bearbeitenden Geschichtswerke im Alten Testament (Darmstadt: Wissenschaftliche Buchgessellschaft, 3rd edn, 1967), pp. 192-217.

${ }^{34}$ W. McKane, A Critical and Exegetical Commentary on Feremiah (ICC; 2 vols; Edinburgh: T. \& T. Clark, 1986, 1996), 1:1-lxxxiii

${ }_{35}$ See also D. T. Olson, The Death of the Old and the Birth of the New: The Framework of the Book of Numbers and the Pentateuch (BJS, 71; Chico, CA: Scholars Press, 1985), p. 49.
5 would better stand together with the laws on adultery in Deut 22.13-15; the law on the Nazirite in Numbers 6 is a general supplement, since Nazirites appear in the Former and Later Prophets (Judg 13.5, 7; 16.17; 1 Sam 1.22 [4QSam ${ }^{a}$; Amos 2.12), but their 'legal situation' is not clarified elsewhere; Numbers 7 contains a supplement to the inauguration of the sanctuary, which relates to the end of Exodus (Num 7.1 even contains an explicit reference to Exodus 40). The prescriptions for the lamp in Num 8.1-4 would stand better after Exod 25.13-15 or 37.12-14. The consecration of the Levites in Num 8.5-7 was apparently written as a supplement to Leviticus 8-9. Numbers 9 contains additional prescriptions for the celebration of Passover, which clarify the prescriptions of Exodus 12.

The same holds true for the prescriptions at the end of the book. Numbers 27 openly states that a certain number of problems linked to the question of heritage are not yet resolved by the existing laws. Interestingly, the final chapter of Numbers (36) adds a supplement and commentary to Numbers 27 (!). The laws about offerings for daily use and on the occasion of festivals (Numbers 28-29) supplement the prescriptions of Leviticus $23 .{ }^{36}$ The regulations concerning vows in Numbers 30 should be understood as actualisation of Deu 23.22-24. The war against the Midianites in Numbers 31 is clearly inspired by the foregoing chapters 22-25, and may also be conceived as antipode to Saul's failure in 1 Samuel $15 .^{37}$ The geographical chapters Numbers 32 and 34-35 have parallels in the book of Joshua; they were possibly taken over from Joshua when the final decision for a Pentateuch (against the alternative Hexateuch) was taken. ${ }^{38}$

${ }^{36}$ This was already observed by Kuenen, who argued that these chapters are at the wrong place: they should belong after Leviticus 23, see A. Kuenen, A Historical Critical Inquiry into the Origin and Composition of the Hexateuch (trans. P. H. Wicksteed; London: Macmillan, 1886), p. 99.

${ }^{37}$ For 1 Samuel 15 as source text for Numbers 31 see E. A. Knauf, Midian: Untersuchungen zur Geschichte Palästinas und Nordarabiens am Ende des 2. Fahrtausends v. Chr (Abhandlungen des Deutschen Palästinavereins; Wiesbaden: Otto Harrassowitz, 1988), p. 167. The influence of the book of Samuel on Numbers is emphasised by A. G. Auld, 'Samuel, Numbers, and the Yahwist-Question', in Gertz, Abschied vom fahwirsten, pp. 233-46.

${ }^{38}$ Numbers 32//Joshua 13; Numbers 34//Joshua 15; Numbers 35//Joshua 21. Achenbach, Vollendung, pp. 557-59 attributes the texts in Numbers to sheocratic redactors located in the fourth century BCE. For the alternative Pentateuch versus Hexateuch in the Persian period see T. Römer and M. Z Brettler 'Deuteronomy 34 and the Case for a Persian Hexateuch', $7 B L 119$ (2000), pp. 401-19. 
The introductory and concluding chapters of Numbers can therefore plausibly be understood as belonging to the very latest texts of the Torah. The same is true for the narrative kernel of the book, especially the theme of never ending rebellions in the wilderness. We will attempt to demonstrate this in what follows.

\section{The Origins of the Wilderness Tradition}

Outside the Pentateuch, Israel's sojourn in the desert is mentioned in some 'historical' Psalms and summaries (especially Josh 24.7; Neh 9.19-21; Pss 78.15-41; 95.8-11;105.40-41; 106.13-15 ${ }^{39}$ ) as well as in some prophetic books (especially Hosea, Amos, Jeremiah, Second Isaiah, Ezekiel). The oldest allusions to the wilderness tradition can possibly be found in Hosea, notwithstanding the complicated history of redaction which this book underwent. ${ }^{40}$ Hosea 9.10 states that Yhwh did find Israel in the wilderness, like grapes or the first fruit on a fig tree. This image clearly evokes a positive relation between Yhwh and Israel's fathers in the wilderness. The problems arose, according to this text, only after Israel entered the cultivated land in Baal-Peor. In a quite similar way, Hos 2.16-17, which belongs to a later redactional stage of the book, announces Israel's restoration with the idea of a return to the desert. Here again the desert symbolises the positive beginnings of Israel's election by Yhwh. A similar vision appears in Jer 2.1-3. This oracle, at the onset of the collection of Jeremiah 2-6, describes the desert time as an experience of taintless love: 'Thus says Yhwh: I remember the affection of your youth, your love as a bride, how you followed me in the

${ }^{39}$ For these psalms see A. H. W. Curtis, 'La mosaïque de l'histoire d'Israël: Quelques considérations sur les allusions "historiques" dans les Psaumes', in D. Marguerat and A. H. W. Curtis (eds.), Intertextualités: La Bible en échos (MdB, 40; Genève: Labor et Fides, 2000), pp. 13-29. Curtis also mentions Pss 135.10-11 and 136.16-20 as containing allusions to Israel's sojourn in the wilderness. Interestingly, these texts mention Israel's victory over the Transjordanian kings without a foregoing period of life in the desert.

${ }^{40}$ See for instance A. A. Macintosh, A Critical and Exegetical Commentary on Hosea. (ICC; Edinburgh: T\&T Clark, 1997) and the presentation of recent research in S. Rudnig-Zelt, 'Die Genese des Hoseabuches: Ein Forschungsbericht', in K. Kiesow and T. Meurer (eds.), Textarbeit: Studien zu Texten und ihrer Rezeption aus dem Alten Testament und der Umwelt Israels: Festschrift fuir Peter Weimar zur Vollendung seines 60. Lebensjahres (AOAT, 294; Münster: Ugarit-Verlag, 2003), pp. 351-86. wilderness, in an uncultivated land' (2.2). Robert Carroll perfectly summed up the ideology of this verse with the following statement: 'The honeymoon was wonderful but the marriage - a complete failure!'41

These texts clearly indicate that the original tradition of Israel's sojourn in the desert was a positive tradition. ${ }^{42}$ The desert appeared as the theatre for the first encounter between Yhwh and Israel. The authors of the quoted texts in Hosea and Jeremiah do not refer to the wilderness traditions of the Torah, as it is often argued. The contrary may be the case: the wilderness stories in Exodus and especially in Numbers should be understood as reinterpretations of a former positive tradition. ${ }^{43}$ Such a reinterpretation can be detected in the first wilderness stories of the book of Exodus.

\section{From Manna to Complaint and Rebellion (Exodus 16)}

Exodus 16 relates the discovery of the manna, which coincides with the discovery of the Sabbath. On the seventh day there is no manna to gather, no work to do. This rhythm that God fixed during the creation, according to Gen 2.1-3, is revealed, after the exodus, to Israel. This link makes it plausible to consider Exodus 16 (or at least parts of it) as belonging to the priestly document. ${ }^{44}$ The priestly writer may have taken over an older aetiology of the manna, which hypothetically can be found in $16.1^{*}, 4 \mathrm{a}, 13 \mathrm{~b}-14 \mathrm{~b} \alpha, 15,21,31{ }^{45}$ If one accepts such a reconstruction it appears that this aetiology did not

${ }^{41}$ R. P. Carroll, feremiah: A Commentary (OTL; London: SCM Press, 1986), p. 119.

${ }^{42}$ Amos 5.25 as well as 2.10 were written by a late redactor, as shown by the theme of 40 years. Interestingly even here the wilderness time is not presented in a negative way (on this see M. Álvarez Barredo, Relecturas Deuteronomísticas de Amós, Miqueas y feremias [Publicaciones del Instituto Teológico Franciscano, Serie Mayor, 10; Murcia: Editorial Espigas, 1993], p. 74). The assertion that during this time Israel did not offer sacrifices to Yhwh (see also Jer 7.22) is either a reminiscence of the pre-priestly wilderness tradition or polemical against the priestly location of the sacrificial laws into the time of the wilderness.

${ }^{43}$ See more details in T. B. Dozeman, 'Hosea and the Wilderness Wandering Tradition', in McKenzie and Römer, Rethinking the Foundations, pp. 55-70.

${ }^{44}$ See E. Ruprecht, 'Stellung und Bedeutung der Erzählung vom Mannawunder (Ex 16) im Aufbau der Priesterschrift', ZAW 86 (1974), pp. 269-307; W. Johnstone, Exodus (OTG; Sheffield: JSOT Press 1990), pp. 82, 110

${ }^{45}$ As suggested by Levin, Fahwist, pp. 77, 352-55. 
contain any mention of a rebellious people. The same absence can be detected in the mention of the manna in Deut 8.3, 16 (here the gift of manna is linked with the idea of a divine pedagogy). ${ }^{46}$ But even in the priestly version of Exodus 16, there is no rebellion and no divine punishment. $\mathrm{P}$ is solely interested in emphasising the importance of the Sabbath for Israel. According to Exod 16.22-24, Moses exhorts the people to make provisions for the seventh day, 'the holy Sabbath for Yhwh'. When the Sabbath has come, Moses urges the people to eat the provisions, because 'today you will not find anything in the field' (vv. 25-26). Nevertheless, according to v. 27, 'on the seventh day some of the people went out to gather, and they found nothing'. Verse 30 relates the logical consequence: 'So the people rested on the seventh day'. In the present text this link between verses 27 and 30 is interrupted by the interpolation of v. 28 (and v. 29): ${ }^{47}$ 'Yhwh said to Moses: How long will you refuse to keep my commandments and instructions?'. This insertion, which reflects deuteronomistic terminology and concerns, transforms the priestly explanation of the Sabbath into a story of rebellion, as do verses 2-3 and 6-12, which emphasise the complaining of the people against Moses and Aaron and which should be also attributed to later redactors. ${ }^{48}$ According to this analysis even the original priestly document (which contained approximately Exod 16.1, 4abo, 13b, 15-17, 21-27, 30-31) was unaware of the idea of ongoing rebellion in the wilderness. The priestly writer apparently took over a positive wilderness tradition close to the one attested in Hosea and Jeremiah.

This hypothesis gets some further support from the analysis of Exod 15.22-27 undertaken by Erik Aurelius. In its present form this text is clearly the work of a post-priestly ${ }^{49}$ redactor. According to Aurelius an earlier form of this story, which provided an aetiology

${ }^{46}$ The idea of testing the people also appears in Exod $16.4 \mathrm{~b} \beta$, which is probably a late attempt to harmonise this story with the deuteronomistic conception of
bent the manna.

See Ruprecht, 'Stellung', pp. 273-74

${ }^{48}$ It is possible that one should distinguish several post-priestly redactions in this chapter.

${ }^{49} \mathrm{~W}$. Johnstone, 'From the Sea to the Mountain, Exodus 15,22-19,2: A Case Study in Editorial Techniques', in M. Vervenne (ed.), Studies in the Book of Exodus: Redaction - Reception - Interpretation: Proceedings of the 44th Colloquium Biblicum Lovaniense BETL, 126; Leuven: Peeters and Leuven University Press, 1996), pp. 245-63 (250), speaks of a composite text which mixes D- and P-material. for Marah, contained only verses $15.22-23$ and 27. The interpolation of vv. 24-25a transformed the aetiology into a story of complaints; verses 25b-26 state that Yhwh already gave commandments and instruction before the revelation on Mount Sinai. This interpolation, which has often caused astonishment among scholars, is in fact necessary to prepare the insertion in Exod 16.28 and may well stem from the same redactor. If the original stories in Exod 15.22-24 and Exodus 16 did not contain the topic of complaint and rebellion one may ask if the same should not also be envisaged for Exodus 17. It is quite clear that the complaint story, which concludes in 17.7 with the aetiology of Massa and Meriba, is inserted in an older context, since 17.8 locates the following story again in Rephidim where the people arrived in $17.1 .^{50}$ The original story would therefore contain a positive account of how Yhwh, after food, provided water in the wilderness (this account can tentatively be reconstructed in $\left.17.1,3 \mathrm{a} \alpha, 5-6^{*}\right)$.

In sum, the few wilderness narratives in the book of Exodus were originally positive accounts of Yhwh's care for his people in the desert, revealing the same ideology as the allusions to the wilderness in Hosea and Jeremiah. This view is also represented by the priestly document. Post-priestly redactors transformed these positive accounts into stories of a complaining people. The invention of a 'cycle of rebellion' in the book of Numbers presupposes this transformation and radicalises the negative view of Israel's sojourn in the wilderness.

\section{The Cycle of Rebellions in Numbers 11-20}

It has already been mentioned that the structure of Numbers is a matter of debate. ${ }^{51}$ Space does not allow me to take up this discussion. It may be enough to keep in mind Olson's seminal work, ${ }^{52}$ rightly emphasising that chapters 1 and 26 , which relate two censuses of the tribes, organise the book according to the idea of two generations:

${ }^{50}$ Johnstone, 'Sea', p. 258, is arguing the other way round and asserts that Rephidim in v. 7 must be secondary, because of Massah and Meribah. ${ }^{51}$ See especially O. Artus, Etudes sur le livre des Nombres: Récit, Histoire et Loi en
Nombres 13,1-20,13 (OBO, 157; Freiburg: Universitätsverlag; Göttingen: Vandenhoeck \& Ruprecht, 1997) pp. 1-40, and W. W. Lee, Punishment Göttingen: Vandenhoeck Migratory Campaign (Grand Rapids: Eerdmans, 2003), pp. 7-46. 
the first which must die in the wilderness and the second which has the possibility to conquer the land. Inside the first part one may distinguish three sections: 1.1-10.36 describing the organisation of the camp and the supplementary prescriptions given before the departure from Sinai; 11.1-20.13 which are situated in the wilderness; 20.14 opens the stories about the occupation of Transjordanian territories. Numbers 25 constitutes an important caesura since Israel's apostasy at Baal-peor marks the end of the first generation. According to this division the sojourn in the wilderness (11.1-20.13) is almost entirely characterised by stories of ongoing conflicts.

One may distinguish seven of those stories. Num 11.1-3 (inspired by Judg 2.6-8, the deuteronomistic introduction of the book of Judges $)^{53}$ functions as an introduction to the whole cycle suggesting a scheme for the following stories: the people complain; Yhwh becomes angry and dispatches punishment; Moses intervenes and the punishment is attenuated. Let us recall that there is no divine punishment after the complaints of the people that have been inserted in Exodus 15-17 (the first divine punishment occurs in Exodus 32 in the story of the golden calf). Numbers 11-20 expresses therefore, a more radical view than the wilderness accounts in Exodus.

The second story in Num 11.4-35 is more complex as suggested by the introduction in 11.1-3: the story combines the people's complaint about the manna and Moses' complaint against Yhwh, whom he accuses for having lain on him the whole weight of the people. At the outcome, the people are punished and Moses discharged. This story clearly presupposes and combines Exodus 16 and 18.

The third narrative (Numbers 12) contains a denial of Moses' authority by Miriam and Aaron, who also criticise him because of his foreign wife; Miriam is punished whereas Moses' exceptional status is confirmed. The fourth story in Numbers 13-14, which is the pivot of the whole cycle, describes the rebellion of the people against the conquest. The plan to return to Egypt provokes Yhwh's anger, who decides the total annihilation of the people. It is only because of Moses' intervention that the punishment is modified: the first generation has to remain in the desert, whereas the second generation gets the chance to conquer the land. Before the fifth narrative, chapter

${ }^{53}$ The presentation of the wilderness in Numbers 11-20 presupposes the deuteronomistic book of Judges.
15 deals with cultic concerns, as do Numbers 18-19. These three chapters frame the two stories, which are concerned with rebellions against the priestly authority. The narrative in 16.1-17.5 combines rebellions of the different groups (Korah and his band, Dathan and Abiram) who oppose Moses and Aaron, claiming the universal priesthood which Yhwh had promised in Exod 19.3-8. In this story Moses does not prevent Yhwh from achieving his punishment. Korah and his followers perish through fire from heaven, and the Sheol swallows Dathan and Abiram.

The sixth story in 17.6-27 is closely related to this account. The people accuse Moses and Aaron of bringing about the divine punishment and criticise the Aaronide priesthood. Again Yhwh's punishment brings death to an important number of rebels. The seventh narrative in Num 20.1-13, which takes up Exodus 17, opens again with a complaint from the people due to the absence of water; but this time the story explains why Moses and Aaron are excluded from entering into the Promised Land. This story provides an answer to a question that remained open in Numbers 13-14. Even if the reason for the divine punishment remains somewhat obscure, it nevertheless appears that Aaron and Moses have to die outside the land because of an individual fault. ${ }^{54}$

One may detect a concentric structure in the organisation of these narratives. ${ }^{55}$ If one excludes the introduction, then 11.4-35 and 20.1-13 are related to each other by the theme of food and beverage; furthermore in both texts Moses is revolting against Yhwh; Numbers 12 deals with the contestation of Moses' authority whereas Numbers 16-17 reject the denial of Aaron's authority. Numbers 13-14 appears as the central contestation: here the people indeed reject the whole divine project of the exodus.

This deliberate organisation does not mean that all these stories should be attributed to the same authors. As already mentioned,

${ }^{54}$ This is a correction of a statement that occurs in Deut 1.37 and 3.36 where Moses is excluded from entering the land because of the fault of the people for whom he is in charge.

11.1-3: introduction

1.4-35: food; Moses' rebellion against Yhwh 12: rebellion against Moses

13-14: rebellion against the exodu

16-17: rebellion against Aaro

20.1-13: beverage; Moses' (and Aaron's) rebellion against Yhwh 
Numbers 20 is certainly later than the first version of $13-14$, and it has always been noticed that most of the stories have also undergone successive redactions.

The task now is to determine the redactional model that applies to these wilderness stories. There is no doubt that all of them are later than the priestly document and the main edition of the Deuteronomistic History, both of which took place during the sixth century BCE. Recently Achenbach has argued for a late date of the wilderness narratives in Numbers. ${ }^{56}$ Following Otto, he attributed most of these texts to two main redactions which edited some older traditions: a Hexateuch-redaction and a Pentateuch-redaction which were supplemented at the end of the fourth century BCE by 'theocratic redactors'. Even though I agree with Achenbach on the late date of the material in Numbers, I am less convinced that one should analyse the whole book with the idea of two thoroughgoing redactions. We mentioned already Noth's insight that the formation of Numbers 27-36 is best explained by successive supplementation; this idea may also apply, at least partially, to Numbers 11-20. An analysis of Numbers 11-12 points in the direction of a 'rolling corpus'. ${ }^{57}$

\section{Numbers 11-12 and the Idea of a 'Rolling Corpus'}

Numbers $11.4-35$ is a composite text, which combines the complaint of the people about the manna and a complaint of Moses about his sole responsibility for the people. The people's complaint has a double achievement. Yhwh sends quail, but the quail cause the death of those who did complain. Moses complaint provokes the gift of Moses' spirit to 70 representatives of the people who become then 'prophets like Moses'. Because of this combination of themes, scholars have often tried to isolate two originally separated documents, ${ }^{58}$

${ }^{56}$ Achenbach, Vollendung, passim.

${ }^{57}$ What follows sums up and supplements my earlier work on these chapters. See T. Romer, Nombres $11-12$ et la question d'une rédaction deutéronomique dans le Pentateuque', in M. Vervenne and J. Lust (eds.), Deuteronomy and Deuteronomic Literature: Festschrift C. H. W. Brekelmans (BETL, 133; Leuven: Peeters and Leuven University Press, 1997), pp. 481-98, and idem, 'Das Buch Numeri und das Ende des Jahwisten: Anfragen zur "Quellenscheidung" im vierten Buch des Pentateuch',

${ }_{58}$ See for instance G. B. Gray, A Critical and Exegetical Commentary on Numbers (ICC; but without much success. ${ }^{59}$ The root 'sp, which is the key word of the chapter, occurs in both topics (vv. 4, 16, 22, 24, 30, 32 [twice]) and the quite Pauline opposition between 'flesh' and 'spirit' also presuppose the combination of the demand of the people and Moses' complaint. ${ }^{60}$ The author of Num 11.4-35 offers a re-reading of Exodus 16 and 18 (or Deut 1.9-18) from the perspective of postexilic prophecy. The story displays numerous allusions to prophetic texts from the Persian period. The people's lament at the beginning of the story: 'our life is dried up' takes over a complaint which is quoted in Ezekiel's vision of the dried bones: 'They say: our bones are dried up' (Ezek 37.11). Yhwh's question to Moses: 'Is Yhwh's hand too short?' (Num 11.23) is the same as in Isa 50.2: 'Is my hand too short?' (cf. 59.1). The theme of the gift of the spirit as well as Moses' wish in 11.29 'Would that all of Yhwh's people were prophets, and that Yhwh would put his spirit on them!', is also a prominent theme in postexilic prophetic literature (Isa 44.3; 46.3; 63.1161; Ezek 36.37; 37.1-5; 39.29; Joel 3.1). The comparison of Yhwh with a mother, which appears in Moses' complaint, is also a common feature of Second Isaiah (Isa 42.14; 46.3; 49.19; 66.13). These facts indicate without any doubt that Num 11.4ff. shares a preoccupation of postexilic prophecy. Frank Crüsemann has pointed out that the Torah, as a priestly-deuteronomistic document of compromise, almost excludes prophecy. ${ }^{62}$ Numbers $11.4-35$ is one of the rare texts in which, at the end of the formation of the Pentateuch, some space was given to a prophetic, charismatic voice. For the prophetic author of this story, the desert also foreshadows Yhwh's final judgement on the rebels. To some degree the divine judgement

Edinburgh: T. \& T. Clark, 1912), p. xxxi, and E. W. Davies, Numbers (NCB; London: Marshall Pickering; Grand Rapids: Eerdmans, 1995), p. 101.

${ }^{59}$ On the intentional complexity of the story see also B. D. Sommer, 'Reflecting on Moses: The Redaction of Numbers 11', JBL 118 (1999), pp. 601-24.

${ }^{60}$ Ruah in the sense of 'spirit' (and fem.) occurs in the episode of the gift of Moses' spirit in vv. 17, 25, 26, 29, whereas it occurs in the sense of 'wind' (masc.) in the quail story in v. 31 .

${ }^{61}$ As Auld, 'Samuel, Numbers, and the Yahwist-Question', p. 242, n. 30, rightly emphasises, this parallel is especially interesting since it obviously alludes to the time of the wilderness.

${ }^{62}$ F. Crüsemann, 'Le Pentateuque, une Tora: Prolégomènes à l'interprétation de sa forme finale', in A. de Pury and T. Römer (eds.), Le Pentateuque en question: les origines et la composition des cinq premiers livres de la Bible à la lumiere des recherches récentes (MdB, 19; Genève: Labor et Fides, 3rd edn, 2002), pp. 339-60 (357). 
in Numbers 11 comes close to the announcement of Yhwh's judgement at the end of the book of Isaiah: 'For by fire will Yhwh execute his judgement, and by his sword all flesh and those slain by Yhwh will be many ... and they shall go out and look at the dead bodies of the people who have rebelled against me' (Isa 66.16, 24). ${ }^{63}$

Besides this transposition of Yhwh's judgement into the desert, the author of Numbers 11 also emphasises an anti-deuteronomistic view of prophecy. As Graeme Auld has emphasised, the story 'revisits the theme, explored also (and probably already) in Exodus and Deuteronomy, of devolving some of Moses' authority on associates' ${ }^{64}$ But whereas in Exod 18.13-27 and in Deut 1.9-18 the issue was on sharing jurisprudential responsibility, the theme of Numbers 11 is about 'democratising' prophecy. According to the deuteronomistic ideology (taken here in a broad sense), there is a prophetic succession that runs from Moses (who according to Deuteronomy 18 is Israel's first prophet) to Jeremiah; the succession from Elijah to Elisha insists on the transfer of the prophetic spirit to the next prophet (2 Kgs 2.9, 15-16). ${ }^{65}$ In the view expressed in Numbers 11 the whole people represented by the 70 elders, is invested with the prophetic spirit, even those who seem to be marginal, such as Eldad and Medad. Against Joshua, who represents in Numbers 11 the (deuteronomistic) orthodox view, Moses himself legitimates prophets who do not depend on him. Such an idea clearly contradicts Deut 18.9-11.66 The idea of the 70 elders is taken over from Exod 24.9-11, a postpriestly and post-deuteronomistic text. ${ }^{67}$ Whereas in Exodus 24 these 'privileged' ones seem to contemplate Yhwh, in Numbers 11 they obtain the privilege of an ongoing prophetic charisma. This was the original idea of Num 11.25, a verse that should be read 'They did

${ }^{63}$ One finds the idea of judgement by fire, which is expressed in Num 11.1, and the insistence on 'flesh' as in Num 11.4. Isaiah 66.16 presents some text-critical problems: LXX adds after nišpa $\bar{a}$ ' the whole earth'; $B H S$ suggests that $b^{e} h a r b \hat{o}$ ('by problems: LXX adds after nispa at 'the whole earth'; $B H, S$
his sword') is an error from $b \bar{a} h a r$, $b \bar{a}$ ('he will examine').

${ }_{64}^{64}$ Auld, 'Samuel, Numbers, and the Yahwist-Question', p. 240.

${ }_{65}$ The author of Numbers 11 was certainly familiar with this story. On the relation between this text and Numbers 11 again see Auld, 'Samuel, Numbers, an the Yahwist-Question', pp. 241-42, who further indicates interesting allusions in Numbers 11 to Samuel and also to Isa 11.2 .

H. Seebass, Numeri (BKAT 4/21-5. Neukirchen-Vluyn: Neukirchener Verlag, 2002), p. 52.

${ }^{67}$ J.-L. Ska, 'Le repas d'Ex 24,11', Bib 74 (1993), pp. 305-27 not stop' (swop), which was later understood and vocalised as 'they did not go on' $(y s p) .^{68}$

Numbers 11 seems to suggest that Moses has no more privileges than the 70 elders; he is even depicted a little ambiguously. Since he expresses doubts on Yhwh's ability to provide meat for the people in vv. $11-15^{69}$ he resembles a rebellious Job, and apparently accuses Yhwh of wickedness. ${ }^{70}$

These statements about Moses and a 'liberated' prophecy did not encounter general agreement. They even triggered the redaction of Numbers 12 as a response and a correction of the views expressed in Numbers 11. Like Numbers 11, Numbers 12 also combines two types of rebellion: a rebellion against Moses as the unique recipient of Yahweh's word (vv. 2-9) and a denigration of Moses' Cushite wife (v. 1 and vv. 10-15). The rebels are Miriam, representing the prophets, and Aaron representing the priests. ${ }^{7}$

Contrary to Numbers 11, Num 12.6-8 highlights the fact that no human being compares to Moses. He alone sees the t'munah of Yhwh, and he stands above all other prophets. This assertion contradicts the idea of Exod 24.9-11 and Num 11.24-30 and goes further than Deut 4.12 and 15; according to these verses the people did not see any temunah of Yhwh during his revelation. Numbers 12.8 separates Moses from the people and brings him into a strong proximity with Yhwh, which is also suggested in Deut 34.10-12 (these verses belong to one of the last redactional layers of the Pentateuch): 'never since has there arisen a prophet in Israel like Moses, whom Yhwh knew face to face....

Moses' incomparability is also expressed by Yhwh's statement that Moses is 'entrusted with all his house'. Moses is here presented as the ideal king, as shown by parallels from the book of Samuel (esp. 1 Sam 22.14) and Near Eastern royal ideology. ${ }^{72}$ The assertion made

${ }^{68}$ Blum, Studien, p. 80; see also Seebass, Numeri, p. 31

${ }^{69}$ On these verses see especially G. J. Wenham, Numbers: An Introduction \& Commentary TOTC, 4; Downers Grove, IL: Inter-Varsity Press, 1981), p. 108 and W. Riggans, Numbers (DSB; Edinburgh: Saint Andrew Press; Philadelphia: Westminster Press, 1983), pp. $90-91$

70 For this understanding of the Tiq. Soph. in v. 15 see Aurelius, Fürbitter, pp. 183-84.

${ }^{71}$ Verse 1 and vv 10-15 sugrest that Miriam was the main agent of this second rebellion.

${ }_{72}$ On the parallels with Samuel see Auld, 'Samuel, Numbers, and the Yahwist- 
in Num 12.3 that 'the man Moses was very humble' can also be understood as a reaction to the presentation of a somewhat choleric Moses in Num 11.11-15.

This defence of Moses' privileged status was complemented by the defence of mixed marriages. ${ }^{73}$ The fact that Miriam is punished because of her attack against Moses' marriage with a Cushite woman reveals an opposition to late deuteronomistic ideology as expressed in Deuteronomy 7, and also in Ezra 9. The author of this story may represent the ideology of a 'liberal' Diaspora Judaism, ${ }^{74}$ which in the Pentateuch is also reflected in the Story of Joseph. Interestingly, this second theme in Numbers 12 not only legitimates marriages with foreign women by a reference to the 'founder' of Judaism; it also insists, like the first theme, on Moses superiority to all other mediators. In vv. 10-15, while Aaron is able to diagnose Miriam's disease, ${ }^{75}$ he is unable to indicate any remedy. He must refer to Moses who intercedes on Miriam's behalf and announces the quarantine to be respected, which is normally done by the priest.

In sum, Numbers 12 presents Moses as the incomparable mediator between Yhwh and Israel to whom the priestly as well as the prophetic functions are clearly subordinated. The author of Numbers 12 tries to correct ideas expressed in Numbers 11, by responding directly to the main assertions of the foregoing chapter. Therefore, it seems impossible to imagine the same redactional level for both chapters although this is done quite often. The fact that Numbers 12 should be understood as a Fortschreibung of Numbers 11 does not mean that the following chapters are necessarily later. The redaction

Question', pp. 243-44; on the Near Eastern context see C. Uehlinger, "'Hat YHWH denn wirklich nur mit Mose geredet?": Biblische Exegese zwischen Religionsgeschichte und Theologie, am Beispiel von Num 12', BZ 47 (2003), pp. 230-59. In the Deuteronomistic History, the title 'Yhwh's servant' is used mainly for Moses and David. Num 12.7 can also be understood as a positive resumption of Num 11.11 ${ }_{73}$ In 'Nombres 11-12' I argued that v. 1 and vv. 10-15 were added by a later redactor. The introduction of the original story in vv. 2-9 would then have been lost or reworked by the later redactor. I concede that it is also possible to imagine that one late author linked both themes, as argued by U. Rapp, Mirjam: Eine feministisch-rhetorische Lektüre der Mirjamtexte in der hebräischen Bibel (BZAW, 317; Berlin: W. de Gruyter, 2002

${ }^{74}$ B. J. Diebner, "For he had married a Cushite woman" (Num 12,1)', Nubica $1 / 2$ (1990), pp. 499-504 thinks that the text may reflect the revendications of the Jews from Elephantine.

${ }^{75}$ Numbers 12 seems to presuppose Leviticus $13-14$. of Numbers cannot be explained by the simple idea of a continuous process of addition of chapters. At the present stage of investigation it is impossible to present a comprehensive model for the whole book. ${ }^{76}$ In the following paragraph I simply try to present, very speculatively, some provisional ideas about the formation of Numbers 11-20.

9. Some Speculations about the Formation of Numbers 11-20

If one looks at Deuteronomy $1-3$, the only rebellion story mentioned in the wilderness is the refusal to conquer the land. Deuteronomy $1.9-40^{*}$, which was probably written before the first edition of Numbers $13-14,{ }^{77}$ is apparently based on an older spy story, which cannot be reconstructed in its original form. ${ }^{78}$ This spy story originated in a negative way, perhaps as a reworking of Josh $7.2-5$ and $18.3-10,{ }^{79}$ in order to demonstrate (as also does the author of Ezekiel 20) that the first conquest of the land had to fail because of the ancestors' stubbornness. In Deuteronomy 1-3, the spy story is immediately followed by narratives about Israel's entry into the Transjordanian territories. This might be an indication that the story behind Numbers $13-14^{*}$ was originally conceived as an introduction to the Transjordanian campaign and only later became the kernel of a 'rebellion cycle'.

The 'prophetic' text of Num 11.4-35 may perhaps be linked with Num 20.1-13*. Both accounts take over stories from the book of Exodus. As in Numbers 11, Moses also appears in Numbers 20 in a rather ambiguous way. The explanation that Yhwh denied Moses

${ }^{76}$ The recent work of Achenbach is, as already mentioned, very impressive, but in my view one should allow for more complexity; one should equally insist on the specificity of Numbers compared to the other books of the Pentateuch. For another recent hypothesis see W. Johnstone, 'Recounting the Tetrateuch', in A. D. H. Mayes and R. B. Salters (eds.), Covenant as Context: Essays in Honour of E. W. Nicholson (Oxford: Oxford University Press, 2003), pp. 209-34

Deuteronomy 1 does not know of any intercession of Moses; for more arguments for the anteriority of Deuteronomy 1 see Blum, Studien, pp. 177-81.

${ }^{78}$ See the recent tentative proposals of Otto, Deuteronomium, pp. 26-86 and R. Achenbach, 'Die Erzählung von der gescheiterten Landnahme von Kadesch Barnea (Numeri 13-14) als Schlüsseltext der Redaktionsgeschichte des Pentateuchs', ZABR 9 (2003), pp. 56-123. Both obtain fragments, but not a continuous story. ${ }^{79}$ The author of the original spy story probably also knew a tradition about the clan of Caleb. 
and Aaron entrance into the land because of their disobedience to a divine order answers a question left open by Numbers 13-14 and meets an important concern of postexilic prophecy; namely, the insistence on individual responsibility (Ezekiel 18; Jer 31.29-30).

According to our interpretation, the priestly class as represented by Aaron, is subordinated to Moses in Numbers 12. Numbers 16-17 could then roughly ${ }^{80}$ be understood as a reaction to Numbers 12 , as an attempt to enhance the status of the Aaronide priesthood. Numbers 17 is also related to Leviticus 10, underlining, despite the fault of Aaron's sons, the holiness of the Aaronides. The rebellion of Dathan and Abiram from the tribe of Ruben could be read as an interpretation of the Transjordanian conquest, as an attempt to explain why (according to the deuteronomistic perspective) these territories are not part of the Promised land. ${ }^{81}$

Given the above considerations it is possible to imagine the growth of Numbers 11-20 in the following way:

(1) Numbers 13-14; (2) Num 11.4-35 and 20.1-13. Here we encounter for the first time the idea of a wilderness time characterised by rebellions of Israel and its leaders. This stage possibly coincides with the transformation of Exodus 15-17 into rebellion accounts; (3) Num 12.2-9 and 12.1, 10-15. Perhaps, the author of these stories also created Num 11.1-3 as an introduction, which like Numbers 12 but against 11.4-35, insists on Moses' intercession. The same author might perhaps also be detected in Num 21.4-9 (the story of the snake plague): here again Moses and Yhwh are almost presented as a 'couple' (see esp. Num 21.5, 7: 'the people came to Moses and said, "We have sinned by speaking against Yhwh and against you ..."') and again all depends on Moses' intercession; ${ }^{82}$ (4) Numbers 16-17, in several stages and probably together with Numbers 15 and 18-19.

All these stages belong to the Persian period. The authors or redactors (it is sometimes not easy to decide which expression fits better) of Numbers 11-20 use the sojourn in the desert as a pretext to sit-

${ }_{81}^{80}$ There is no doubt that Numbers $16-17$ has grown in two or three stages. ${ }^{81}$ According to U. Schorn, 'Rubeniten als exemplarische Aufrührer in Num 16-17*/Deut 11', in McKenzie and Römer, Rethinking the Foundations, pp. 251-68, the texts about Datan and Abiram are altogether very late, post-deuteronomistic and post-priestly.

${ }^{82}$ That Num 21.4-9 belongs to the very last layers of the Pentateuch is convincingly argued by Aurelius, Fürbitter, p. 152. uate their own claims. As argued previously, the time in the desert was also extended because the foregoing books, as well as Deuteronomy, were more or less closed when the book of Numbers started to grow. Despite their ideological differences, all texts in Numbers 11-20 agree on the idea that Israel's sojourn in the wilderness was a time of ongoing rebellions and conflicts. In this sense Mary Douglas is certainly right when she claims that the book of 'Numbers complements the other books [of the Pentateuch] by presenting a coherent mythic background for Judah's political situation after the exile'. ${ }^{83}$

In the Deuteronomistic History, Israel's rebellion that led to destruction and exile mainly started after the conquest (see for instance 2 Kings 17); for the book of Numbers there was already continuous rebellion before the entry into the land. This is perhaps linked to the fact that when Deuteronomy was cut off from the following books, the so-called Deuteronomistic History came to stand outside of the 'Torah'. Since 'exile' (in a mythical sense) and life outside the land had become important aspects of the 'Jewish identity' which originated during the Persian period, there was the need to strengthen life outside the land in the Pentateuch and to foreshadow the divine judgement, which was necessary for the 'new identity' of Israel. And this was the origin of the book of Numbers.

\section{Some Concluding Remarks and an Invitation to an Ongoing Debate}

'Israel's sojourn in the wilderness' was not one of the traditional themes which gave rise to the Pentateuch. On the contrary, the idea of a long period characterised by numerous conflicts and rebellions is a late invention, linked with the creation of the book of Numbers. The present debate about the formation of the Pentateuch has shown that it has become very difficult to postulate a Yahwist, or a D-composition, or even a P-document that would have covered the totality of the present narrative structure of the Pentateuch. The idea of the Torah as a compromise between a priestly and a 'deuteronomistic' group still remains a valuable thesis. But this compromise

${ }^{83}$ M. Douglas, In the Wilderness: The Doctrine of Defilement in the Book of Numbers (JSOTSup, 158; Sheffield: JSOT Press, 1993), p. 98. 
started perhaps in other ways than often argued. To my mind there was a confrontation between a priestly document comprising Genesis-Leviticus ${ }^{84}$ and the Deuteronomistic History. At a first stage, there was agreement to separate Deuteronomy from the following books. As a matter of pure speculation one could even imagine that Deuteronomy was first attached at the end of Leviticus. This would present at least a quite smooth transition, which avoids some 'doublets' between Numbers and Deuteronomy. The fact that the first and the last parts of Numbers contain laws and other texts, which would have fit better in Exodus, Leviticus or Deuteronomy indicates that the scroll of Numbers was created at the very end of the process of canonisation of the Torah when the need was felt to integrate some new laws and also narratives.

If this idea has some pertinence it would have a double consequence. First, one should ask if there is any need that one model should apply for the formation of all books of the Pentateuch Deuteronomy, for instance, is best explained by the model of successive redactions, whereas Exodus 1-15 suggests the model of two independent accounts that were later combined. Numbers, I have argued, needs the model of a rolling corpus combined with the search for 'final' redactors of the Pentateuch. Second, we probably need to reinvestigate the commonly shared assumption that the separation of the Torah into five books happened at the very end of its formation. Each book of the Torah, Numbers excepted, has its specific profile, which is not just due to the opening and concluding verses. Therefore one should allow for the idea that books such as Genesis ${ }^{85}$ or Deuteronomy did circulate as independent scrolls before becoming part of the Torah, as Joseph Blenkinsopp has rightly emphasised: 'Since we do not know the circumstances in which any of the biblical books, including the Pentateuch, were first written, we cannot

${ }^{84}$ One should also recall the testimony of Hecateus of Abdera, who seems to refer to a 'Torah' that possibly ended with Lev 27.34. See for instance L. L. Grabbe, 'Jewish Historiography and Scripture in the Hellenistic Period', in L. L. Grabbe (ed.), Did Moses Speak Attic? Fewish Historiography and Scripture in the Hellenistic Period (JSOTSup, 317; European Seminar in Historical Methodology, 3; Sheffield: Sheffield Academic Press, 2001), pp. 129-55 (131-33).

${ }^{85}$ The organisational technique of the toldot is limited to the book of Genesis. This may indicate that the priestly authors or redactors themselves wanted to underline the specific character of this book, even if they saw it as the first part of a history which continued in Exodus. assume that the Pentateuchal narrative existed in continuous form and was then, for whatever reasons broken up into five sections' ${ }^{86}$ This idea would also explain why some parts of the Pentateuch were apparently 'stable' earlier than others and why there was a need to create the book of Numbers as a theatre of scribal interpretations and discussions, which will come to their zenith in Mishna and Talmud.

\footnotetext{
${ }^{86}$ Blenkinsopp, Pentateuch, p. 45. For the process of writing and canonisation see especially P. R. Davies, Scribes and Schools: The Canonization of Hebrew Scriptures (Library of Ancient Israel; Louisville, KY: Westminster/John Knox Press, 1998) and J. Barton, 'Canons of the Old Testament', in A. D. H. Mayes (ed.), Text in Context: Essays by Members of the Society for Old Testament Study (Oxford: Oxford University Press, 2000), pp. $200-22$.
} 